\title{
Students' information literacy needs: competencies for teacher-librarians in the twenty-first century
}

\section{KEN HAYCOCK}

\author{
Director, School of Library, Archival and Information Studies, \\ University of British Columbia, Vancouver, B.C. Canada VG T \\ 121,email: slais@unixg.ubc.ca
}

\begin{abstract}
In 1995 Association for Teacher-librarianship in Canada (ATLC) and the Canadian School Library Association (CSLA), a division of the Canadian Library Association, established a joint committee to define the competencies necessary for effective teacher-libranians for the twenty-first century. The project was intended to revise the Canadian School Library Association's Qualifications for Teacher-librarians (1979) and to serve the needs of both teacher-librarians and educational administrators.

The joint committee of the ATLC and the CSLA comprised Joan Harper (CSLA), Ken Haycock (ATLC/CSLA Chair), Judith Kootte (CSLA), and Pat Parungao (ATLC), with the assistance of $\mathrm{Liz}$ Austrom; each draft statement was revised in consultation with a national response panel and provincial and national education groups and associations. The first preliminary draft was distributed in May, 1996 for response; the second was distributed in April, 1997; the final draft was distributed to the each association's executive committee in June, 1997. This final draft was approved with minor editorial changes and prepared for distribution in July, 1997.

This document is based on prior work by the Association for Teacher-librarianship in Canada and the Canadian School Library Association as well as the intellectual work and graphic design of the Special Libraries Assaciation (Washington, DC). Research evidence fonmed the underpinning $s$ of the drafts and was reported in the scholarly and professional joumals and monographs in Australia, Canada, the United Kingdom and the United States. These resources provide a recent Canadian perspective:

This paper presents the professional and personal competencies required for effective teacher-librarians; the conference presentation focuses on the process of development and plans for implementation.
\end{abstract}

\section{Introduction}

Students in Canada today need to be able to think rationally and logically. With more and more sources of information, both print and electronic, and the increasing difficulty of ensuring that students can derive meaning from this information, the role of the teacher-librarian becomes central. Teacher-librarians are skilled in accessing and evaluating information regardless of delivery system, book or computer, and providing leadership in the appropriate use of newer information technologies.

Education for All: Culture, Reading and Information, IASL, 1998 
There is a significant body of research that demonstrates that a qualified teacher-librarian has a positive impact on school culture and student achievement. Indeed, several studies have established that teachers collaborate more in schools with a teacher-librarian and students read more, enjoy reading more, write better, access and use information more effectively and excel in academic content areas. This does not happen by chance, however.

In these schools information literacy is incorporated into school and classrooms programs because:

- the program is recognized as a partnership of the principal, teacher and teacher-librarian, supported by the school district and community;

- the district insists on flexible scheduling [the teacher-librarian is not the preparation time or "relief" for classroom colleagues];

- the principal encourages collaboration and team teaching through this flexible schedule;

- teachers acknowledge that the processing and use of information is a school-wide concern, for integration with classroom content instruction;

- the teacher-librarian takes the initiative, places a priority on cooperative program planning and teaching with colleagues and encourages team planning.

The teacher-librarian is a highly skilled teacher, with competencies provided by a combination of teacher education, classroom experience and courses in teacher-librarianship and information studies. The teacher-librarian should be in the forefront of curriculum and staff development, familiar with the full range of instructional strategies and learning styles, able to organize time and resources, and active in professional concerns within the school and the district.

In approving this document, school boards, agencies and professional associations affirm the research evidence that indicates that integrated library programs impact positively on collaboration, leadership and student achievement when the teacher-librarian has experience as a classroom teacher, qualifications in teacher-librarianship and information studies and learning resources management, preferably at the graduate level, and works collaboratively with teachers in flexibly scheduled programs to integrate information problem-solving skills and strategies in the ongoing instructional program.

\section{The competent feacher-librarian}

The competent teacher-librarian is committed to

the principles outlined in the Student's Bill of Information Rights;

implementing curriculum with colleagues;

initiating collaboratively planned and taught programs to integrate information literacy in the context of the curriculum; and

the effective use of information technologies.

Professional competencies relate to the teacher-librarian's knowledge and skill in the areas of collaboration and leadership, curriculum and instruction, collaborative program planning and teaching, information resources, information access, technology, 
management and research, and the ability to apply these abilities as a basis for providing library and information services.

Personal competencies represent a set of skills, attitudes and values that enable teacher-librarians to work efficiently and effectively, be good communicators, focus on continuing learning throughout their careers, demonstrate the value-added nature of their contributions and thrive in the new world of education.

The following sections highlight the major professional and personal competencies of teacher-librarians and provide practical examples of the multitude of roles and tasks that teacher-librarians can perform. The examples are illustrative and are tempered by critical factors such as the nature of school leadership and culture, the climate for collaboration and innovation in the work environment, flexible scheduling, the time allocation of professional and support staff and the specific education and training of the teacher-librarian to do the job.

\section{Professional competencies}

The teacher-librarian:

1.1. places a priority on staff relationships and leadership in the implementation of change.

Examples: Establishes rapport with school staff, students and the community. Develops a collaborative approach with the principal, teachers and other staff. Provides an environment conducive to learning. Keeps abreast of and communicates developments in curriculum, instructional strategies, and newer information technologies. Participates in the school's governance by serving on advisory and decision-making bodies.

1.2. provides leadership in collaborative program planning and teaching to ensure both physical and intellectual access to information and commitment to voluntary reading.

Examples: Advocates the integration of information skills and strategies in classroom programs through collaborative program planning and team teaching with colleagues. Develops with teachers a coordinated approach to information literacy, including decision-making, problem-solving and research strategies, integrated with classroom instruction. Understands and distinguishes between physical and intellectual access to information. Provides leadership for reading and research programs, incorporating both informational and imaginative literature. Plans and teaches with teachers from establishing objectives through to student assessment and unit evaluation.

1.3. knows curriculum programs mandated by the province, district and school.

Examples: Is aware of new curricula and implications for implementation. Provides support for teachers through training and implementation. Understands the appropriate integration of resources and technologies with specific curriculum areas. Promotes congruence of stated learning outcomes, delivered curriculum, assessment and supporting resources and technologies.

1.4. understands students and their social, emotional, and intellectual needs.

Examples: Understands child and adolescent growth and development for the age levels of the school. Can relate to student needs and interests. Works with teachers and others to 
match resources to a variety of learning styles and requirements and to adapt the curriculum and program for students with special needs.

1.5. has expert knowledge in evaluating learning resources in different formats and media, both on-site and remote, to support the instructional program.

Examples: Works within written school and district policies on the selection of learning resources and their appropriate use. Works within a written school policy on the purchase and management of all school resources and their access. Evaluates print, CD-ROM and on-line versions of databases. Selects the best books, journals, non-print and electronic resources for specific curriculum areas and specific learning outcomes using authoritative selection "tools". Organizes teacher involvement in evaluation. Compiles guides to resources both on and off site. Develops and manages a collection of quality materials that reflect resource-based units of study.

1.6. develops and promotes the effective use of informational and imaginative resources in all formats through cooperative professional activities.

Examples: Promotes voluntary reading throughout the school. Develops themes and celebrations that reflect the school's curriculum and unique community. Designs and produces materials for specific instructional purposes, where commercial materials are not available. Assists students and teachers in the effective use of resources and technologies.

1.7. provides appropriate information, resources or instruction to satisfy the needs of individuals and groups.

Examples: Recommends learning resources for specific learning outcomes. Works with individuals and groups to identify problems, frame questions, check authority, evaluate information and develop critical thinking. Provides guidance on accessing information appropriate to the specific need. Understands the design and structure of bibliographic and other databases. Conducts searches from complex or difficult sources. Answers questions using on-site and remote resources. Assists students and teachers with using authoring tools in print, electronic and multimedia formats. Supports colleagues who are accessing information services from the classroom.

1.8. uses appropriate information technology to acquire, organize and disseminate information.

Examples: Establishes, maintains and teaches the use of an on-line catalog of the library collection. Works on information management teams to select appropriate software, hardware and security for desktop access. Contributes to a home page for the World Wide Web for the school. Links the library page to other relevant curriculum sites. Informs school community of copyright issues. Keeps up-to-date with new products and modes of information delivery. Plans and participates in the development and provision of information networks.

1.9. manages library programs, services and staff to support the stated educational goals of the school.

Examples: Develops an integrated library program linked to the curricular goals of the school. Develops procedures for the cost-effective selection, acquisition, organization, management and use of resources. Manages professional and support staff. Recruits, selects, trains and motivates volunteers. Manages space and equipment. Maintains an 
inventory of materials and equipment. Plans and manages a budget which reflects the instructional program. Develops a marketing plan for specific audiences. Plans strategies for securing support for learning resource services in the school and community.

1.10. evaluates program and services.

Examples: Actively seeks opportunities for improvement and strives for excellent programs and services. Involves school staff in program evaluation. Conducts regular needs assessments using research tools such as questionnaires, focus groups and interviews. Prepares oral and written reports on program development. Reports regularly and confers with the principal and staff on program implementation. Conducts research related to the solution of information management problems. Demonstrates how library and information services add value to the school. Refocuses programs and services on new needs.

\section{Personal competencies}

The teacher-librarian:

2. 1 . is committed to program excellence.

Examples: Seeks feedback and uses it for continuous improvement. Celebrates own success and that of others. Takes pride in a job well done. Shares new knowledge with others at conferences and in the professional literature. Uses the research base of education and teacher-librarianship as a resource for improving services.

2.2. seeks out challenges and sees new opportunities both inside and outside the library.

Examples: Takes on new roles in the school community that require an information leader. Uses library-based knowledge and skills to solve a variety of information problems. Expands the library collection beyond traditional media such as books and journals. Creates the "library without walls".

\section{3. sees the big picture.}

Examples: Recognizes that information seeking and use are part of the creative process for individuals. Sees the library and its information services as part of the bigger process of making informed decisions. Anticipates trends and pro-actively realigns library and information services to take advantage of them.

\section{4. looks for partnerships and alliances.}

Examples: Provides leadership in information management. Forms partnerships with other libraries for resource sharing. Seeks alliances with vendors to improve products and services. Seeks alliances with researchers in education and library and information studies to conduct relevant studies.

2.5. creates an environment of mutual respect and trust.

Examples: Knows own strengths and the complementary strengths of others. Is dependable. Values and acknowledges the contributions of others in a problem-solving environment.

2.6. has effective communications skills. 
Examples: Runs meetings effectively. Presents ideas clearly and enthusiastically both orally and in writing. Requests feedback on communications skills and uses it for self improvement.

2.7. works well with others in a team.

Examples: Seeks out opportunities for team participation. Asks for mentoring from others when needed. Looks for ways to enhance personal performance.

\section{8. provides leadership.}

Examples: Exercises leadership as a member of teams within the school and community. Seeks opportunities for leadership.

2.9. plans, prioritizes and focuses on what is critical.

Examples: Recognizes that ongoing planning and time management are required. Reviews goals with administrators and colleagues on a regular basis.

2.10. is committed to lifelong learning.

Examples: Advocates for a learning environment to encourage the contributions of staff members. Participates in professional associations.

2.12. is flexible and positive in a time of continuing change.

Examples: Willing to take on different responsibilities and respond to changing needs. Maintains a positive attitude and helps others to do the same. Looks for solutions. Uses technology as an enabler.

\section{Students' Bill of Information Rights}

Our students face an information-rich future in which change will be one of the few constants of their life experience. Their ability to adapt and fulfill their individual potentials will require them to be life-long learners and independent decision-makers.

We believe that all students should have the opportunity to:

master the skills needed to access information in print, non-print and electronic sources;

understand and master effective research processes and reporting skills;

develop the ability to evaluate, extract, synthesize and utilize information from a variety of sources and media;

utilize data and information to expand their own knowledge base;

explore the creative use of information;

develop an understanding of our Canadian cultural heritage and history, as well as cultures and histories of other societies;

enhance their own self knowledge through developing a love of reading;

explore the values and beliefs of others by reading world literature;

think critically, and make decisions based on personal needs and values as well as upon factual evidence, and

actively participate in decisions about their own learning. 
Information is a vital component in the development of critical thought and independent decision-making, and, consequently, access to the ever-increasing body of available information is vital to the development of students' potentials.

We believe that all students should have the right to:

access a wide range of print, non-print and electronic learning resources at an appropriate level;

explore materials expressing a variety of opinions and perspectives, and freely choose reading, viewing and listening materials for recreational and study purposes.

\section{Glossary of terms}

Teacher-librarian: A professional teacher with a minimum of two years of successful classroom experience and additional qualifications in the selection, management and utilization of learning resources, who manages the school library and works with other teachers to design and implement resource-based instructional programs.

School library: The instructional center in a school that coordinates and provides on site and off site access to information, resources, services and programs that integrate information literacy, the intellectual access to information, with teachers, to develop independent learners who are effective users of information and ideas and committed to informed decision-making.

School library program: The collaboratively planned and taught units of study developed through the shared expertise and equal partnership of classroom teachers and teacher-librarians, based on the principles of resource-based learning and designed to achieve the educational goals of the school.

Support staff: Under the direction of a teacher-librarian, may include graduates of a post-secondary library technician program who organize and maintain the resources and equipment and provide reference and technical support services to teachers and students; clerical staff who provide support services in areas such as acquisition, circulation and processing of resources, and typing or word processing; adult and student volunteers.

Information literacy: The ability to: recognize the need for information to solve problems and develop ideas; pose important questions; use a variety of information gathering strategies; locate relevant and appropriate information; access information for quality, authority, accuracy and authenticity. Includes the abilities to use the practical and conceptual tools of information technology, to understand form, format, location and access methods, how information is situated and produced, research processes, and to format and publish in textual and multimedia formats and to adapt to emerging technologies. 


\section{Provincial guidelines}

Newfoundland and Labrador:

Learning to learn: Policies and guidelines for the implementation of resource-based learning in Newfoundland and Labrador schools. Newfoundland and Labrador Department of Education, 1991.

Prince Edward Island:

School library policy for the province of Prince Edward Island. Prince Edward Island Department of Education, 1989.

Nova Scotia:

Nova Scotia school libraries: Standards and practices. Nova Scotia Teachers Union, 1987.

New Brunswick:

Standards and practices for New Brunswick school libraries. New Brunswick Teachers Association Library Council, 1989.

Quebec:

Les bibliothèques scolaires Québécoises: Direction générale d'evaluation et des resources didactiques. Also: Library resources in the schools: Pedagogical and organizational aspects. Québec Ministère de l'Education, 1987.

Ontario:

Partners in action: The library resource centre in the school curriculum. Ontario Ministry of Education, 1982. Also: Information literacy and equitable access: A framework for change. Ontario Ministry of Education, 1995.

Manitoba:

Resource-based learning: An educational model. Manitoba Education and Training, 1994.

Saskatchewan:

Resource-based learning: Policies, guidelines and responsibilities for Saskatchewan learning resource centres. Saskatchewan Education, 1988.

Alberta:

Focus on learning: An integrated program model for Alberta school libraries.

Alberta Education, 1985. Also: Focus on research: A guide to developing student's research skills. Alberta Education, 1990.

British Columbia:

Developing independent learners: The role of the school library resource centre. British Columbia Ministry of Education, 1991.

Northwest Territories: 
Guidelines for the development of school information centres. Northwest Territories Education, 1990.

\section{Education for teacher-librarianship}

Amey, L. (1992). Education for teacher-librarians in Canada: A national study. Ottawa: Canadian School Library Association. (Canadian School Library Association Occasional Paper). Available from Dalhousie University School of Library and Information Studies, Halifax, NS B3H $4 \mathrm{H} 8$, Canada.

Canadian School Library Association. Guidelines for effective school library programs [series]. Canadian School Library Association. "Rationale", School Libraries in Canada, 8:4 (Summer, 1988), p. 30. "Clossary", School Libraries in Canada 9:3 (Spring, 1989), p. 45. 'Program Advocacy", School Libraries in Canada 10:4 (Summer, 1990), pp. 19-27. 'Key Roles", School Libraries in Canada 12:1 (Winter, 1992), pp. 8-14. 'Leadership", School Libraries in Canada 12:2 (Summer, 1992), pp. 16-27. "School Library Program", School Libraries in Canada 13:3 (Fall, 1993), pp. 20-21.

Haycock, K. (1996). Teacher-librarianship: Bridging the gap between research and practice. In J. Webb (Ed.), Sustaining the vision; Selected papers from the 24th annual conference of the International Association of School Librarianship, Worcester College of Education, Worcester, England, July 17-21, 1995 (pp. 11-17). Seattle, WA: International Association of School Librarianship.

Haycock, K. (1995). Research in teacher-librarianship and the institutionalization of change. In D. Adcock (Ed.), Literacy: Traditional, cultural, technological; Selected papers from the 23rd Annual Conference of the International Association of School Librarianship, School of Library and Information Science, University of Pittsburgh, Pittsburgh, Pennsylvania (pp. 94-103). Kalamazoo, MI: International Association of School Librarianship. Reprinted: In K. Haycock \& B. Woolls (Eds. ). School librarianship: International issues and perspectives (pp. 69-79). Seattle, WA: International Association of School Librarianship, 1997; In L. A. Clyde (Ed.), Sustaining the vision: A collection of articles and papers on research in school librarianship (pp. 13-22). San Jose, CA: Hi Willow Research and Publishing, 1996; In School Library Media Quarterly, 23, 227-233.

Haycock, K. (Ed.). (1982). Education for school librarianship in Canada, Ottawa, ON: Canadian Library Association. $78 \mathrm{pp}$. Incorporates (1981) A recommended curriculum for education for school librarianship. Ottawa, ON: Canadian School Library Association (Also: School Libraries in Canada, 1(4), 3-11); and (1979). The qualifications of school librarians. Ottawa, ON: Canadian Library Association (Also: The Bookmark, 21(1), 3 7; Alberta Learning Resources Journal, 3(3), 3-8;Media Newfoundland, 10(1), 59.Moccasin Telegraph, 22, 11-15, among others); prepared by the CSLA Committee on Qualifications for School Librarians (Liz Austrom, Dave Boettcher, Stan Copland, Gerry Gibb, Ken Haycock (convenor), Debbie Porteous). 